Article

\title{
Carotenoid-Producing Yeasts: Identification and Characteristics of Environmental Isolates with a Valuable Extracellular Enzymatic Activity
}

\author{
Karolina Chreptowicz ${ }^{1, *}$, Jolanta Mierzejewska ${ }^{1} \mathbb{1}$, Jana Tkáčová ${ }^{2}$, Mateusz Młynek ${ }^{1} \mathbb{C}$ and \\ Milan Čertik ${ }^{2}$ (1) \\ 1 Drug and Cosmetic Biotechnology, Faculty of Chemistry, Warsaw University of Technology, \\ 00-664 Warsaw, Poland; jmierzejewska@ch.pw.edu.pl (J.M.); mlynekk.m@gmail.com (M.M.) \\ 2 Institute of Biotechnology, Faculty of Chemical and Food Technology, Slovak University of Technology, \\ 81237 Bratislava, Slovakia; jane.tkacova@gmail.com (J.T.); milan.certik@stuba.sk (M.Č.) \\ * Correspondence: karolina.chreptowicz@pw.edu.pl
}

Received: 31 October 2019; Accepted: 3 December 2019; Published: 4 December 2019

check for updates

\begin{abstract}
Sixteen cold-adapted reddish-pigmented yeast strains were obtained from environmental samples. According to the PCR-based detection of classical yeast markers combined with phylogenetic studies, the yeasts belong mainly to the genera Rhodotorula, Sporobolomyces and Cystobasidium, all within the subphylum Pucciniomycotina. All strains produced carotenoids within a $0.25-10.33 \mathrm{mg} / \mathrm{L}$ range under non-optimized conditions. Noteworthily, among them, representatives of the Cystobasidium genus were found; of particular value are the strains C. laryngis and C. psychroaquaticum, poorly described in the literature to date. Interestingly, carotenoid production with representatives of Cystobasidium was improved 1.8- to 10-fold at reduced temperature. As expected, most of the isolated yeasts biosynthesized extracellular lipases, but within them also one proteolytic and four cellulolytic strains were revealed. We succeeded in isolating strain Cystofilobasidium macerans WUT145 with extraordinarily high cellulolytic activity at $22^{\circ} \mathrm{C}(66.23 \pm 0.15 \mu \mathrm{mol} / \mathrm{mg}$ protein.min) that is described here for the first time. Consequently, a set of yeasts capable of producing both carotenoids and extracellular enzymes was identified. Taking into account those abilities, the strains might be applicable for a development of carotenoids production on an agro-industrial waste, e.g., lignocellulose.
\end{abstract}

Keywords: basidiomycetes; carotenoid pigments; impact of temperature; cellulolytic yeasts

\section{Introduction}

Yeast of the class basidiomycetes prevail among fungi in polar regions [1] and it is estimated that, to date, no more than $5 \%$ of the species existing in Nature has been recognised (approx. 50 genera and 250 species). With significant agricultural and medical importance, this group of microorganisms has gained increasing interest among scientists both in terms of their biodiversity and ecological roles, as well as from an economic point of view. It has been found that several basidiomycetous yeasts have a great impact on bio- control of plant diseases, whereas others can break down aromatic compounds and are therefore considered useful in bioremediation [2]. In addition, under particular conditions several fungal species are capable of accumulating lipids in so-called lipid bodies (LB) accounting for up to $65 \%$ of their dry biomass. These lipids are of great interest for the cosmetics industry, for several reasons, e.g., emolliency, lubricity; and for the pharmaceutical industry, as delivery agents to provide more homogeneous and efficient application and transport of active agents [3]. Furthermore, some basidiomycetous yeasts produce pigments, mainly carotenoids (also called tetraterpenoids) such as $\gamma$ and $\beta$-carotene, torulene and torularhodin (Rhodotorula spp. and Sporobolomyces roseus), or astaxanthin 
(Phaffia rhodozyma) [4-10]. Natural pigments constitute about 30\% of the dyeing substances market [11]. In response to the growing legal restrictions on the use of artificial food additives, under both European and USA legislation, new methods of obtaining natural dyes are widely sought after. Carotenoids are one of the most common classes of pigments, with the global market estimated at nearly $\$ 1.4$ billion in 2018, and forecasted to reach $\$ 1.5-1.8$ billion for 2019-2020 [12,13]. They are widely used in the food, pharmaceutical, cosmetic and the nutrition industries. Not just useful as colorants, carotenoids are important molecules in protecting the human and animal body against photo-oxidative damage, including cataracts, an in skin protection and cancer prevention [14-16]. Some of them are vitamin A precursors, and thus are marked as high-value nutritional molecules.

Although the microbial production of carotenoids has been extensively studied for a long time, their industrial-scale production remains uneconomical. To reduce the costs of production it would be worthwhile to utilize agricultural waste, e.g., lignocellulose and whey. However, this is no simple task, since these residues are unlikely to be fermented by microorganisms, and need to be pre-treated and hydrolyzed prior to fermentation. This generates additional costs, which could be reduced by applying microorganisms not only capable of producing large amounts of carotenoids, but also of secreting extracellular hydrolase enzymes. Besides, the agricultural wastes are rich in carbon sources, e.g., xylose, cellobiose or lactose, which are not commonly fermented by yeasts. Although several basidiomycetes yeast species were reported to produce hydrolases (e.g., polysaccharases, lipases) [17] or ligninolytic enzymes [18], we still know very little about their application in bioprocesses, e.g., converting organic waste into carotenoids. Among the basidiomycetes the least studied group of yeasts constitute members of the Cystobasidium genus. The search for diversity in Nature recently led to the recognition of new yeast species within the Cystobasidium genus, such as Cystobasidium oligophagum, Cystobasidium laryngis, Cystobasidium iriomotense. They appear to be capable of converting agro industry by-products, and have been proposed as oil or enzyme producers [19-21]. Thus, it is of great interest to further explore this field and search for new basidiomycetes yeast and examine their biotechnological potential.

In this study, a set of sixteen reddish-pigmented yeast strains were isolated from plant and food samples, and subsequently characterized with a particular emphasis on their potential for carotenoid, lipid and extracellular enzyme production.

\section{Materials and Methods}

\subsection{Isolating the Yeast Strains}

The yeast strains were isolated with the procedure previously described in [22] and their molecular characterization is described in the present manuscript. The exception is strain $R$. mucilaginosa WUT10, which has been isolated previously and initially described in [22]. In brief, samples of plant material were spread on standard YPD agar plates (10 g/L yeast extract (Biocorp, Warsaw, Poland), $20 \mathrm{~g} / \mathrm{L}$ peptone (Biocorp), $20 \mathrm{~g} / \mathrm{L}$ glucose (Bioshop, Burlington, ON, Canada) and $20 \mathrm{~g} / \mathrm{L}$ agar (Biocorp)), supplemented with ampicillin and streptomycin providing a final concentration of 100 and $20 \mathrm{mg} / \mathrm{L}$ respectively. The plates were then incubated for $2-4$ days at $25^{\circ} \mathrm{C}$. The single colonies growing on plates were streaked once again and incubated $2-4$ days at $25^{\circ} \mathrm{C}$.

\subsection{Polymerase Chain Reaction and the Sequencing of rDNA Fragments}

Classical yeasts markers (ITS and D1/D2) were used to identify yeast species. The total DNA of the selected strains was extracted and amplified by PCR with a pair of NL4 (5'GGTCCGTGTTTCAAGACGG3') and ITS1 (5'TCCGTAGGTGAACCTGCGG3') primers, as described previously [23]. The products of reactions were purified and sequenced (Genomed S.A., Warsaw, Poland). The sequences were deposited in the NCBI GenBank database (Table 1). 
Table 1. Molecular identification of isolated yeast strains based on the sequences of ITS and D1/D2 regions in genomic DNA. *Based on BLASTn search and phylogenetic analysis. ${ }^{* *}$ Containing partial $18 \mathrm{~S}$ rRNA gene, ITS1, 5.8S rRNA gene, ITS2 and partial 26S rRNA gene. *** Sequences were submitted to the NCBI GenBank database and are publicly available.

\begin{tabular}{|c|c|c|c|}
\hline Strain & Source & Identification * & $\begin{array}{c}\text { Sequence Length of } \\
\text { Genomic DNA (bp)**/ } \\
\text { GenBank Accession } \\
\text { Number } * * *\end{array}$ \\
\hline WUT10 & $\begin{array}{l}\text { Fermented milk, } \\
\text { Antalya, Turkey }\end{array}$ & Rhodotorula mucilaginosa & 1120 / MN006686 \\
\hline WUT57 & $\begin{array}{l}\text { Wild strawberry shrub, } \\
\text { Toulouse, France }\end{array}$ & Rhodotorula graminis & 1111 / MN006688 \\
\hline WUT60 & Pepper, Warsaw, Poland & Rhodotorula mucilaginosa & 1112 / MN006694 \\
\hline WUT61 & $\begin{array}{l}\text { Beech tree, Barania } \\
\text { Mountain, Poland }\end{array}$ & Sporobolomyces roseus & 1110 / MN006697 \\
\hline WUT89 & $\begin{array}{c}\text { Birch bark, Słowiński National } \\
\text { Park, Poland }\end{array}$ & Cystobasidium laryngis & 1072 / MN006700 \\
\hline WUT92 & $\begin{array}{c}\text { Birch bark, Słowiński National } \\
\text { Park, Poland }\end{array}$ & Cystobasidium sp. & 968 / MN006698 \\
\hline WUT103 & Birch bark, Warsaw, Poland & Cystobasidium laryngis & 1103 / MN006701 \\
\hline WUT117 & Mirabelle, Warsaw, Poland & $\begin{array}{c}\text { Cystobasidium } \\
\text { psychroaquaticum }\end{array}$ & 1101 / MN006705 \\
\hline WUT128 & Sow-thistle, Turku, Finland & Rhodotorula graminis & 1018 / MN006772 \\
\hline WUT145 & Tree leaf, Cork, Ireland & Cystofilobasidium macerans & 1156 / MN006771 \\
\hline WUT147 & Red grapes, Warsaw, Poland & Rhodotorula graminis & 1005 / MN006773 \\
\hline WUT159 & Apple, Warsaw, Poland & Sporidiobolus pararoseus & 1092 / MN006774 \\
\hline WUT165 & Apple, Warsaw, Poland & Rhodotorula graminis & 1097 / MN006776 \\
\hline WUT167 & Rowanberry, Warsaw, Poland & Rhodotorula mucilaginosa & 1105 / MN006818 \\
\hline WUT182 & Quince, Riga, Latvia & Sporobolomyces roseus & 1095 / MN006819 \\
\hline WUT194 & Grapes, Warsaw, Poland & Rhodotorula graminis & 1107 / MN006820 \\
\hline
\end{tabular}

\subsection{Phylogenetic Analysis}

Phylogenetic analyses of the obtained sequences were made according to [24] in MEGA-X Program. At first, nucleotide BLAST analysis was done and sequences of reference strains with the sequences of the closest relevant strains (cut-off level: $Q_{\text {cover }} \geq 85 \%$ and Identity $\geq 90 \%$ ) were further used in multiple-alignment using MUSCLE program. Aligned sequences were used to construct the phylogenetic tree.

\subsection{Characterization of Isolated Yeast}

Newly isolated yeast strains were checked for the growth on various carbon sources using solid media containing: $6.7 \mathrm{~g} / \mathrm{L}$ yeast nitrogen base with ammonium sulphate without amino acids (Conda, Madrid, Spain), 20 g/L agar and, respectively, 20 g/L D-glucose, D-xylose (Carl Roth, Karlsruhe, Germany), D-galactose (Carl Roth), lactose (POCH, Gliwice, Poland), D(+)-sucrose (Bioshop), $\mathrm{D}(+)$-cellobiose (Fluka, Buchs, Switzerland) or glycerol (Bioshop) as a single carbon source at $25^{\circ} \mathrm{C}$ for 2-4 days. Furthermore, the yeast growth on a rich solid YPD medium was also tested at various temperatures, both low and high, in a range between $4-42^{\circ} \mathrm{C}$.

\subsection{Screening for Extracellular Enzymes Production}

Isolated yeasts were characterized in terms of their extracellular enzymes production by qualitative plate assays. The selected yeast cultures were grown for $2-3$ days at $22{ }^{\circ} \mathrm{C}$ on plates containing the following media: the lipase activity was detected on Spirit Blue agar (Becton Dickinson, New Jersey, USA) with $20 \%(\mathrm{v} / \mathrm{v})$ emulsion olive oil/Tween 80 , the protease activity was tested on nutrient agar supplemented with skimmed milk and cellulase activity on yeast nitrogen base with ammonium 
sulphate without amino acids (Conda) with $20 \mathrm{~g} / \mathrm{L}$ carboxymethylcellulose (CMC) (Sigma Aldrich, St. Louis, MO, USA). The expression of lipase and protease enzymes was confirmed by a zone of clearance around the colony. In case of cellulolytic activity, a positive result was indicated by light halos surrounding isolated colonies after pouring Lugol's iodine onto the plate.

\subsection{Determining Cellulolytic Activity in a Plate Assay and Liquid Assay}

Selected strains were cultivated overnight in Sabouraud broth at $22{ }^{\circ} \mathrm{C}$ and later diluted in a YPDC medium containing $10 \mathrm{~g} / \mathrm{L}$ yeast extract, $20 \mathrm{~g} / \mathrm{L}$ peptone, $10 \mathrm{~g} / \mathrm{L}$ glucose and $10 \mathrm{~g} / \mathrm{L} \mathrm{CMC}$. The yeast cultures were grown for 4 days at $22{ }^{\circ} \mathrm{C}$ and agitated at $240 \mathrm{rpm}$ in Lab Companion SI-600R bench top shaker (Ramsey, MN, USA). Supernatants containing extracellular proteins were obtained by centrifuging the yeast cultures at 10,000 $\mathrm{g}$ for $5 \mathrm{~min}$ at $4{ }^{\circ} \mathrm{C}$ (Sorval Evolution RC Centrifuge, Thermo Scientific, Waltham, MA, USA). The biomass was discarded and the total protein content in the supernatant was determined using the Bradford method.

For CMC degradation plate test, $10 \mu \mathrm{L}$ of cell-free supernatants containing extracellular proteins were spotted onto the plates containing $2 \% \mathrm{CMC}$. Plates were incubated overnight at $22{ }^{\circ} \mathrm{C}$. CMC degradation was indicated by light halos surrounding the spots after pouring Lugol's iodine onto the plate.

A quantitative liquid enzyme assay was carried out according to the methods of International Union of Pure and Applied Chemistry (IUPAC) [25]. For cellulolytic activity, $0.5 \mathrm{~mL}$ of supernatant was incubated with $0.5 \mathrm{~mL}$ of $2 \% \mathrm{CMC}$ in a sodium citrate buffer $(0.05 \mathrm{M}, \mathrm{pH} 4.8)$ at $22^{\circ} \mathrm{C}$ for $17 \mathrm{~h}$. Following the incubation, the reaction was terminated by adding $3.0 \mathrm{~mL}$ of DNS reagent (3,5-dinitrosalicylic acid, IUPAC name 2-hydroxy-3,5-dinitrobenzoic acid) to $1 \mathrm{~mL}$ of reaction mixture. The probes were incubated in a hot water bath for $5 \mathrm{~min}$, and then cooled in a cold water bath, followed by sample dilutions. The concentration of the reducing sugars obtained were measured spectrophotometrically (Rayleigh VIS-7220G Spectrophotometer, Rayleigh Analytical Instruments, Beijing, China) displaying a standard glucose curve. The enzymatic activity was defined as $\mu \mathrm{mol} / \mathrm{mg}$ protein.min.

\subsection{Carotenoids Production in Liquid Cultures}

A loop full of material was used to inoculate $20 \mathrm{~mL}$ of YPD medium in $100 \mathrm{~mL}$ Erlenmeyer flask. All cultures were grown in triplicate at $15^{\circ} \mathrm{C}, 20^{\circ} \mathrm{C}, 22^{\circ} \mathrm{C}$ or $25^{\circ} \mathrm{C}$, and agitated at $180 \mathrm{rpm}$ in Lab Companion SI-600R bench top shaker.

Overnight cultures were diluted in 100-mL Erlenmeyer flasks containing $20 \mathrm{~mL}$ of production medium [10]: $20 \mathrm{~g} / \mathrm{L}$ glucose (in selected cases $30 \mathrm{~g} / \mathrm{L}$ or $40 \mathrm{~g} / \mathrm{L}$ ), $2 \mathrm{~g} / \mathrm{L}\left(\mathrm{NH}_{4}\right)_{2} \mathrm{SO}_{4}$ (Avantor, Gliwice, Poland), $1 \mathrm{~g} / \mathrm{L} \mathrm{KH}{ }_{2} \mathrm{PO}_{4}, 0.5 \mathrm{~g} / \mathrm{L} \mathrm{MgSO}{ }_{4}$ (Avantor), $0.1 \mathrm{~g} / \mathrm{L} \mathrm{CaCl} 2$ (Avantor), $2 \mathrm{~g} / \mathrm{L}$ yeast extract, $\mathrm{pH} 4.9$, to a final concentration of $10^{6} \mathrm{cells} / \mathrm{mL}$, and were cultivated for 4 days at $15^{\circ} \mathrm{C}, 20^{\circ} \mathrm{C}, 22^{\circ} \mathrm{C}$ or $25^{\circ} \mathrm{C}$ and agitated at $180 \mathrm{rpm}$. All cultures were grown in the Lab Companion SI-600R bench top shaker. All experiments were performed in four parallel cultivations.

\subsection{Isolation of Total Carotenoids and Lipids from Yeast Biomass}

Isolation of total carotenoids and lipids was conducted as described previously [26]. In a few words, cells were harvested via centrifugation at $5000 \mathrm{rpm}$, for $5 \mathrm{~min}$, RT (Rotina 380 Hettich Zentrifugen, Hettich $\mathrm{GmbH} \& \mathrm{Co}$., Tuttlingen, Germany), rinsed twice with $0.9 \% \mathrm{NaCl}$ solution and finally with distilled water. The yeast biomass was frozen, lyophilized and subsequently homogenized with mortar sea sand (Lach-Ner, Neratovice, Czech Republic). Carotenoids, together with lipids, were extracted twice with a chloroform/methanol $(2: 1 \mathrm{v} / \mathrm{v})$ mixture for $1.5 \mathrm{~h}$ at RT. The extracts were washed with distilled water (1.2-fold of total extract volume), stirred vigorously and centrifuged to obtain phase separation. The chloroform layer was filtered through anhydrous $\mathrm{Na}_{2} \mathrm{SO}_{4}$ and evaporated under a vacuum. The carotenoid extracts were re-suspended in n-hexane (99\%, HPLC grade) or in mixture n-hexane/chloroform (9:1) where necessary. The total lipid content (L) was 
determined gravimetrically [26]. Carotenoid distribution was analyzed by high performance liquid chromatography (HPLC).

\subsection{Dry Biomass Estimation}

One $\mathrm{mL}$ probes from the 4-day production cultures were used to estimate the dry cell weight (DCW). The cells were harvested by centrifugation in pre-weighed tubes at 13,000 rpm for $3 \mathrm{~min}$, RT (Mikro220 Hettich Zentrifugen), rinsed twice with $0.9 \% \mathrm{NaCl}$ solution and once with distilled water. The tubes were dried for $2 \mathrm{~h}$ at $100^{\circ} \mathrm{C}$ and then weighed again. The dry biomass content was calculated using the difference between the weight of the tube with dried biomass and the empty tube. Biomass production was expressed as $\mathrm{g} / \mathrm{L}$.

\subsection{HPLC Analysis of Residual Sugars in Culture Media and Carotenoid Pigments Extracted from Yeast Biomass}

Twenty $\mu \mathrm{L}$ of sample was injected into the column (SETREX IEX H $+300 \times 8 \mathrm{~mm}$ column, Polymer IEX H form, $8 \mu \mathrm{m}$ ) and the sugars content was analyzed using HPLC (SYKAM chromatograph, Sykam $\mathrm{GmbH}$, Eresing, Germany combined with a RI detector set at $35^{\circ} \mathrm{C}$ and with thermostatic control at $35^{\circ} \mathrm{C}$ in order to avoid fluctuations in detector responses). Samples were eluted isocratically using $5 \mathrm{mM} \mathrm{H}_{2} \mathrm{SO}_{4}$ as the mobile phase, at the flow rate $1 \mathrm{~mL} / \mathrm{min}$. The residual glucose was identified using the recognised standard; under these conditions glucose eluted at $5.2 \mathrm{~min}$.

Twenty $\mu \mathrm{L}$ of carotenoid extract was injected into the column (BIONACOM Velocity CRT column; $250 \times 4.6 \mathrm{~mm}, 5 \mu \mathrm{m}$ ) and the carotenoid composition was analyzed using HPLC (SYKAM S 1125) equipped with a diode array detector (DAD). The applied solvents were acetone (solvent $\mathrm{A}$ ) and water (solvent B). The solvent flow rate was $1 \mathrm{~mL} / \mathrm{min}$ with a gradient of $80 \% \mathrm{~A}, 20 \% \mathrm{~B}$ at $0 \mathrm{~min}, 100 \% \mathrm{~A}$ at $12 \mathrm{~min}, 100 \% \mathrm{~A}$ at $18 \mathrm{~min}, 80 \% \mathrm{~A}$ and $20 \% \mathrm{~B}$ at $19 \mathrm{~min}$, and maintained for $30 \mathrm{~min}$. The carotenoid pigments were identified using the recognised standards: $\beta$-carotene (Sigma Aldrich), $\gamma$-carotene (CaroteNature, Münsingen, Switzerland), and torulene (CaroteNature), torularhodin (CaroteNature)).

\section{Results and Discussion}

\subsection{Identification of Yeasts Isolated from Plant Samples}

Through screening various plant samples fifteen new red-pink pigmented yeast strains were isolated. Based on sequences of 26S rDNA (D1/D2 domain) and internal transcribed spacer (ITS) region sequences, and using BLAST in the GenBank database combined with phylogenetic analysis, these strains were assigned into five genera (Rhodotorula, Sporobolomyces, Sporidiobolus, Cystobasidium and Cystofilobasidium) of Basidiomycota division (Table 1, Figure 1). R. mucilaginosa WUT10, the previously isolated strain [22], was also included into the present study.

In phylogenetic studies of yeast isolates five main groups were recognised. In the first group, there are five strains directly related to genus R. graminis (marked in blue). These strains show slight differences in nucleotide sequences on a common fragment, and between strains WUT194, WUT165 and WUT57 only a six nucleotide (nt) divergence was estimated, whereas between WUT194, WUT128 and WUT147, $5 \mathrm{nt}$ and $7 \mathrm{nt}$, respectively. The second group comprises of strains related to R. mucilaginosa species (marked in green). The highest difference in nucleotide sequence (10 nt) was determined between WUT60 and WUT167, whereas between WUT60 and WUT10 variance in only $6 \mathrm{nt}$ was denoted. Next three strains, WUT159, WUT181 and WUT61, formed individual branches with one direct homologue and were assigned into Sporidiobolus pararoseus and Sporobolomyces roseus species. In the fourth cluster, there were located strains WUT117, WUT89, WUT103 and WUT92 of Cystobasidium genera. In the case of WUT92, phylogenetic analysis did not allow to clearly assign this isolate to the species. It cannot be excluded that WUT92 is a representative of new species, but more complex analysis is required. 


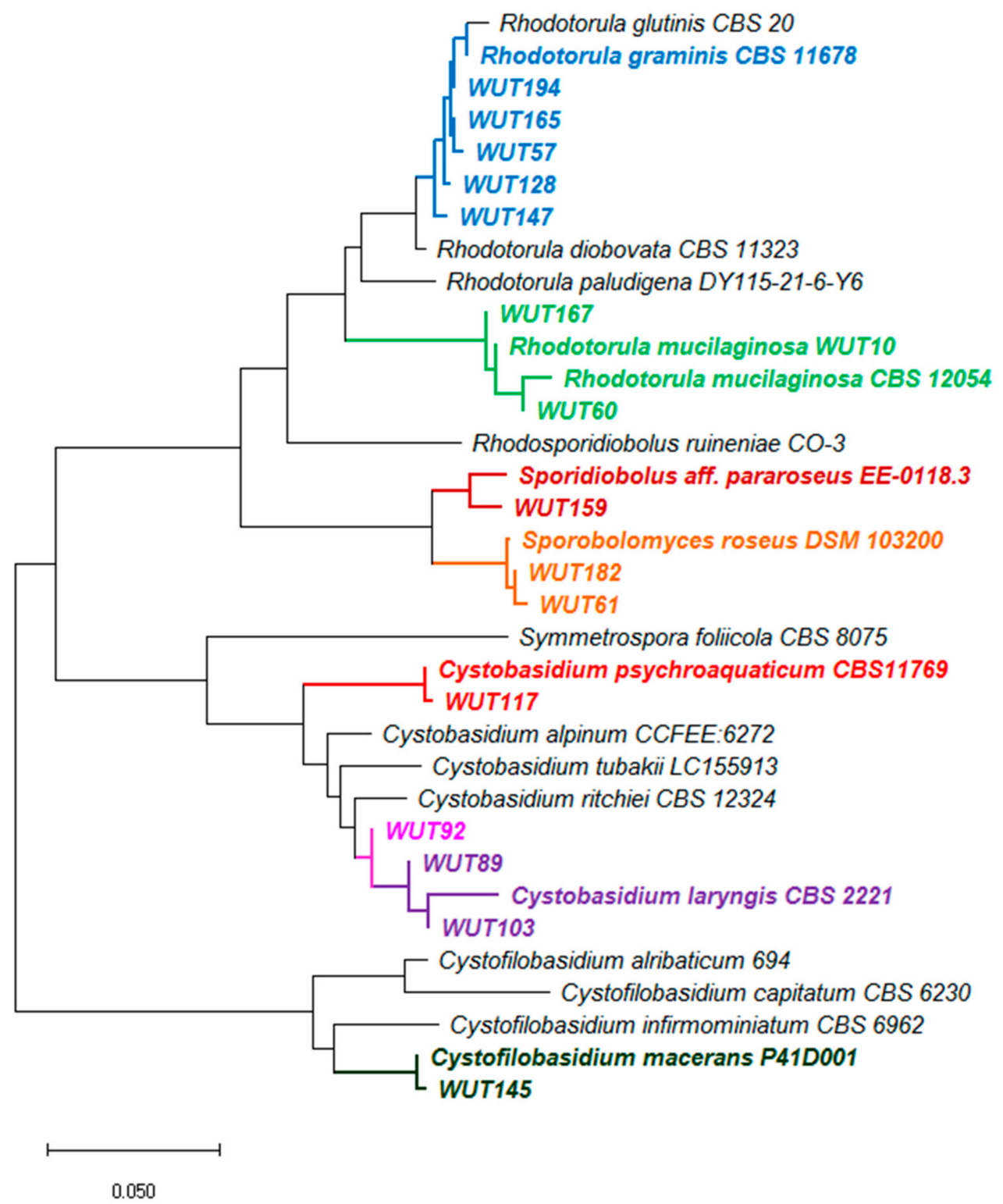

Figure 1. Neighbor-Joining tree showing phylogenetic relationship constructed from the evolutionary distance data for 18S rRNA(partial sequence)-ITS1-5.8S rRNA-ITS2-28S rRNA (partial sequence). The optimal tree with the sum of branch length $=0.93$ is shown. The evolutionary distances were computed using the $\mathrm{p}$-distance method and are in the units of the number of base differences per site. This analysis involved 34 nucleotide sequences. Codon positions included were 1 st+2nd+3rd+Noncoding. All ambiguous positions were removed for each sequence pair (pairwise deletion option). There were a total of 3349 positions in the final dataset. Evolutionary analyses were conducted in MEGA X [27].

\subsection{Physiological and Biochemical Characteristic of Yeasts}

The initial characterization of the newly isolated strains included: morphological (microscopic observations and determining cells size; Table S1), physiological and biochemical analyses (therein, ability to utilize various carbon sources, range of temperature growth and extracellular enzymes production; Table 2 and Figures S1-S3). Growth observations revealed that all strains metabolize the standard carbon source-glucose, and most of them are also capable of multiplying on a medium containing glycerol (13 strains), cellobiose (13 strains), xylose (13 strains) or maltose (11 strains). Besides, seven isolates, mainly from Rhodotorula genus grow well on galactose. As for the range of temperatures, for all 16 strains growth at $25^{\circ} \mathrm{C}$ was observed, while at the elevated temperatures it 
was limited. However, nine strains are able to multiply at $30^{\circ} \mathrm{C}$ and one, R. mucilaginosa WUT167, at $37^{\circ} \mathrm{C}$. It was observed that the temperature range of growth can vary, even for strains belonging to the same species. Namely, the strains identified as R. mucilaginosa WUT10 and WUT60, unlike WUT167, exhibited growth up to $30^{\circ} \mathrm{C}$. Similarly, for two Sporobolomyces roseus strains, the maximum growth temperature varied between $25^{\circ} \mathrm{C}$ and $30^{\circ} \mathrm{C}$ for WUT61 and WUT182, respectively.

Although many enzymes with industrial applications are produced using yeasts [28-30], new and safe sources of enzyme preparations are still being sought. Therefore, the ability of newly isolated strains to produce extracellular enzymes was also verified (Table 2). Several yeasts have been described as lipase producers, and among them species of the genus Candida are the most commercially used ones [31]. However, lipase-producing basidiomycetes species have also been isolated and characterized [2,20, 32-35]. In accordance with recent reports, in this study most of the strains were able to synthesize lipases and gave positive results in the plate tests (Table 2 and Figure S1), w hereas, a proteolytic activity was only demonstrated for Cystofilobasidium macerans WUT145 (Figure S2). Till now only one paper has described protease production by yeast from the Cystofilobasidium genus [36], however, other cold-adapted yeasts belonging to basidiomycetes were previously characterized as potential protease producers [37,38]. Additionally, within the tested strains, four of them, Sporobolomyces roseus WUT61, C. macerans WUT145, S. pararoseus WUT159 and S. roseus WUT182, produced clear positive results for cellulolytic activity in the plate test (Figure S3). It is worthwhile noting that the authors are un aware of any works evaluating the potential of Cystofilobasidium or Sporobolomyces species for cellulases production, and little has been published about $R$. glutinis with cellulolytic ability [39].

The ability to utilize various carbon sources, especially combined with the extracellular hydrolytic enzymes production is desired in term of designing bioprocesses conducted in media based on agricultural waste (e.g., lignocellulosic biomass in form of straw), which is rich in polymers composed of sugars like glucose, xylose, galactose or cellobiose. Thus, the cellulolytic activity of the isolated yeasts was studied in more detail and presented below.

\subsection{Synthesis of Cellulases by Selected Yeasts}

Cellulases are the enzymes responsible for the hydrolysis of cellulose into sugars, and cellulose is the most abundant source of renewable energy on the planet. Therefore, cellulases are widely applied in various sectors, such as food, detergent, laundry, textile, baking and bio-fuels industries. However, the commercially available cellulolytic enzymes are mostly active at elevated temperature, about $40-50{ }^{\circ} \mathrm{C}$, like one of the most popular enzyme coctail Cellic ${ }^{\circledR}$ CTec2 and HTec2 [40]. One of the key requirements in these processes is to reduce the costs of heating, leading to a search for microorganisms, especially psychrotolerant ones, that secrete cellulases active at moderate temperatures. To date, very few studies have reported the production of cellulases by yeasts, mainly Rhodotorula mucilaginosa [41], Aureobasidium pullulans [42] or Pseudozyma brasiliensis [43]. Thus, the search for new cellulolytic yeast is of a great importance. From the preliminary screening described above, four strains (S. roseus WUT61, C. macerans WUT145, S. pararoseus WUT159 and S. roseus WUT182) with this trait were found (Table 2). They were then subjected to further analyses in terms of cellulolytic activity, by applying two assays plate and liquid ones. Yeast cultures were grown for 4 days at $22^{\circ} \mathrm{C}$ in an YPDC medium containing $1 \%$ carboxymethylcellulose $(\mathrm{CMC})$ to induce the production of cellulases. The cellular-free supernatants were then tested for cellulolytic activity. For all tested supernatants, light halos were observed in plate assay, which indicated the cellulose degradation (Figure 2). 
Table 2. Physiological and biochemical characteristics of isolated yeast strains. YNB-yeast nitrogen base, GLU—glucose, XYL—Xylose, GAL—Galactose, LAC—lactose, SAC—saccharose, GLY—glycerol, EtOH—ethanol, CEL—cellobiose, MAL—maltose. ${ }^{\text {a }}$ As a positive result, discoloration of the medium around colonies is observed. No changes in medium colour indicate negative result. ${ }^{b, c}$ Positive result: Appearance of transparent zones around the colonies. No changes indicate negative result. "-" no growth/negative result, "+" growth/positive result, "w" weak growth/activity.

\begin{tabular}{|c|c|c|c|c|c|c|c|c|c|c|c|c|c|c|c|c|}
\hline \multicolumn{17}{|c|}{ Strain Number in WUT Collection } \\
\hline & 10 & 57 & 60 & 61 & 89 & 92 & 103 & 117 & 128 & 145 & 147 & 159 & 165 & 167 & 182 & 194 \\
\hline \multicolumn{17}{|c|}{ Growth (assimilation) on carbon compounds } \\
\hline YNB + GLU & + & + & + & + & + & + & + & + & + & + & + & + & + & + & + & + \\
\hline YNB + XYL & + & $\mathrm{w}$ & $\mathrm{w}$ & - & + & + & + & + & + & $\mathrm{w}$ & $\mathrm{w}$ & - & - & $\mathrm{w}$ & - & - \\
\hline YNB + GAL & + & $\mathrm{w}$ & + & - & - & + & - & - & + & - & + & $\mathrm{w}$ & + & + & - & $\mathrm{w}$ \\
\hline YNB + LAC & - & - & - & - & - & - & - & - & - & - & - & - & - & - & - & - \\
\hline YNB + SAC & + & + & + & + & + & + & + & + & + & - & + & + & + & + & + & + \\
\hline YNB + GLY & + & $\mathrm{w}$ & - & + & + & + & + & + & + & $\mathrm{w}$ & $\mathrm{w}$ & $\mathrm{w}$ & - & $\mathrm{w}$ & - & $\mathrm{w}$ \\
\hline YNB + EtOH & - & - & - & $\mathrm{w}$ & + & - & $\mathrm{w}$ & $\mathrm{w}$ & + & $\mathrm{w}$ & $\mathrm{w}$ & - & - & $\mathrm{w}$ & - & $\mathrm{w}$ \\
\hline YNB + CEL & - & + & - & $\mathrm{w}$ & $\mathrm{w}$ & + & + & + & + & + & + & + & + & + & $\mathrm{w}$ & $\mathrm{w}$ \\
\hline YNB + MAL & + & + & + & + & - & - & - & - & + & + & + & + & + & + & + & - \\
\hline \multicolumn{17}{|c|}{ Range of temperature growth (YPD medium, 2-3 days) } \\
\hline$\left[{ }^{\circ} \mathrm{C}\right]$ & $4-30$ & $4-30$ & $4-30$ & $4-25$ & $4-25$ & $4-25$ & $4-25$ & $4-25$ & $4-30$ & $4-25$ & $4-30$ & $4-30$ & $4-25$ & $4-37$ & $4-30$ & $4-30$ \\
\hline \multicolumn{17}{|c|}{ Extracellular enzymes production } \\
\hline Lipase activity $^{a}$ & + & + & + & + & $\mathrm{w}$ & $\mathrm{w}$ & $\mathrm{w}$ & $\mathrm{w}$ & + & + & + & - & + & + & $\mathrm{w}$ & + \\
\hline Protease activity ${ }^{b}$ & - & - & - & - & - & - & - & - & - & + & - & - & - & - & - & - \\
\hline Cellulase activity ${ }^{c}$ & - & - & - & + & - & - & - & - & - & + & - & + & - & - & + & - \\
\hline
\end{tabular}




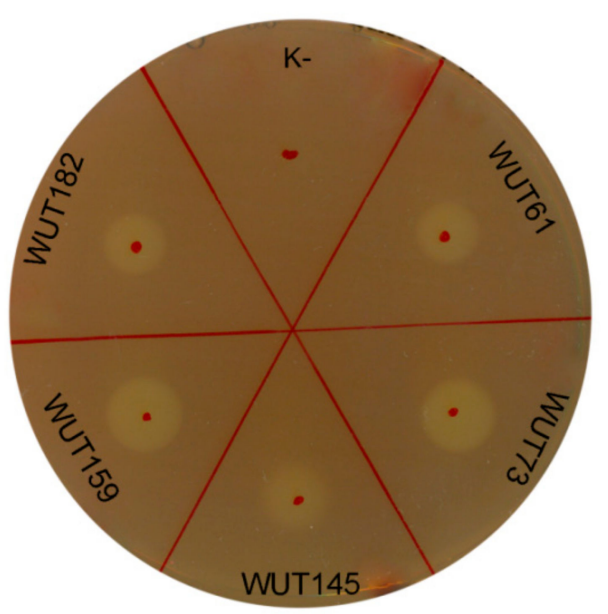

Figure 2. Cellulolytic activity determined by plate assay. Ten $\mu \mathrm{L}$ of cell-free supernatants from 4-days liquid cultures were spotted onto the plates containing $2 \% \mathrm{CMC}$. Plates were incubated overnight at $22^{\circ} \mathrm{C}$ and stained with Gram's iodine solution after incubation. As a positive control, cellulolytic strain Aureobasidium pullulans WUT73 was used. "K-" - negative control (10 $\mu \mathrm{L}$ of pure medium).

Although the halo diameters were similar for each supernatant culture, the cellulolytic activities determined in liquid enzyme assay revealed significant differences (Table 3). The cellulolytic activity obtained for strain S. pararoseus WUT159, which exhibited the highest halo diameter $(11.0 \pm 0.0 \mathrm{~mm})$ in the plate test, was the lowest and reached a rate of merely $0.30 \pm 0.10 \mu \mathrm{mol} / \mathrm{mg}$ protein $\cdot \mathrm{min}$, while for C. macerans WUT145, with the smallest halo diameter $(8.7 \pm 1.4 \mathrm{~mm})$ in plate test, a value over 20 times higher was obtained, $66.23 \pm 0.15 \mu \mathrm{mol} / \mathrm{mg}$ protein $\cdot \mathrm{min}$. Several factors may have influenced the results obtained in plate test, which can be considered more qualitative rather than quantitative, as has also been discussed by others [44]. Consequently, tests carried out in liquid seem to be more credible. The WUT145 strain exhibited extraordinary cellulolytic activity, and, to the authors' best knowledge, this is the first report which demonstrates the $C$. macerans strain with the above-mentioned characteristic. In addition, unlike for commercially available cellulases which are active at $40-50{ }^{\circ} \mathrm{C}$, the strong cellulolytic activity of WUT145 strain was determined at $22{ }^{\circ} \mathrm{C}$, which is highly desired by the industry. Also, for the Sporobolomyces genus strains, no reports on cellulolytic activity can be found. Thus, the results obtained here can be considered promising and it would be worthwhile to continue research on cellulolytic activity of selected strains, especially on C. macerans WUT145.

Table 3. Cellulolytic activity of four selected strains expressed as halo diameter in a plate assay and CMC activity in liquid enzyme assay. ${ }^{*}$ Measured in duplicate from two biological repetitions $(n=4)$.

\begin{tabular}{ccc}
\hline Strain & Halo Diameter $[\mathrm{mm}]$ & CMC Activity* $[\mu \mathrm{mol} / \mathbf{m g}$ Protein*min] \\
\hline WUT61 & $9.7 \pm 0.5$ & $0.65 \pm 0.21$ \\
WUT145 & $8.7 \pm 1.4$ & $66.23 \pm 0.15$ \\
WUT159 & $11.0 \pm 0.0$ & $0.30 \pm 0.10$ \\
WUT182 & $10.0 \pm 1.4$ & $3.54 \pm 0.76$ \\
WUT73 (K+) & $11.3 \pm 0.9$ & $1.55 \pm 0.09$ \\
\hline
\end{tabular}




\subsection{Preliminary Evaluation of Carotenoid Production}

Based on the colour of the colony, 16 yeast strains were tested for carotenoid biosynthesis. The studies assume that the optimum temperature for the production will be $25^{\circ} \mathrm{C}$ (maximum temp. growth observed for all tested strains in previous studies). Although the first eight strains (WUT10-WUT117) cultivated at $25^{\circ} \mathrm{C}$ exhibited moderate growth (estimated biomass production (X) was between 4.5-7.4 g/L), the remaining eight strains (WUT128-WUT194) grew poorly under the tested conditions. Therefore, the temperature was reduced to $22{ }^{\circ} \mathrm{C}$. This change resulted in a considerable improvement in yeast growth (calculated X was between 6-9.7 g/L) (Table 4). Together with the biomass measurements, at the end of the culture, residual glucose concentration was also estimated by HPLC. Glucose was only determined in the cultures of 3 strains: Cystobasidium laryngis WUT89, Cystobasidium laryngis WUT103 and Cystobasidium psychroaquaticum WUT117, the remaining strains utilized the dextrose present in medium. After a 4-day incubation, yeast biomass was used to determine the lipids and carotenoids content.

\subsubsection{First Test Group—Strains WUT10-WUT117}

The total carotenoid content $\left(\mathrm{C}_{\mathrm{C}}\right)$, expressed as mg carotenoids/g biomass (Table 4 ), varied between the tested strains, even for those belonging to the same genera. Strains WUT10 and WUT60 identified as R. mucilaginosa exhibited a 2-fold difference in total carotenoid content $(0.23 \pm 0.02$ vs $0.11 \pm 0.01 \mathrm{mg}$ carotenoids/g biomass, respectively). No direct correlation between the yeast growth and the carotenoid production was observed, yet there may be a connection between carotenoid production and glucose intake. The least amount of carotenoids was determined in the strain cultures where the glucose was not entirely consumed (0.05-0.09 $\mathrm{mg}$ carotenoids/g biomass). For strains that utilized all the glucose during the 4-day incubation, the carotenoid content was almost 3.6-times higher (0.16-0.32 mg carotenoids/g biomass). The highest production, $0.32 \pm 0.04 \mathrm{mg}$ carotenoids/g biomass, was estimated for Cystobasidium sp. WUT92 strain.

As demonstrated in this study, identifiable carotenoids also differ between tested strains. R. mucilaginosa is known from biosynthesizing $\beta$-carotene as the major carotenoid [4]. However, species of $R$. mucilaginosa producing other carotenoids in predominance can also be found, eg. torularhodin [45]. Two strains R. mucilaginosa isolated within this study synthesized mainly torulene and torularhodin; this trait may be strain- and medium-specific.

For Cystobasidium strains, C. laryngis WUT89, C. laryngis WUT103 and C. psychroaquaticum WUT117, $\gamma$-carotene and $\beta$-carotene are the main synthesized carotenoids. For the best yeast producer from this test group, Cystobasidium sp. WUT92, all four carotenoids, of almost the same amount, were detectable (Table 4). Interestingly, strains from the genus Cystobasidium are not yet well characterized, especially in terms of the production of carotenoids. 
Table 4. Four day carotenoid production cultures of isolated yeast strains at $25^{\circ} \mathrm{C}$ and $22{ }^{\circ} \mathrm{C}$. X-biomass production, $\mathrm{L}-$ lipidic extract, $\mathrm{C}_{\mathrm{C}}-$ total carotenoid content, $\mathrm{Y}_{\mathrm{C}}$-carotenoid output, nd-not detected, a-the average cannot be calculated; * bolded names denote a predominant dye. ${ }^{*}$ highest values.

\begin{tabular}{|c|c|c|c|c|c|c|}
\hline Strain & $X[g / L]$ & Residual Glucose $[\mathrm{g} / \mathrm{L}]$ & L $[\mathrm{mg}]$ & $\mathrm{C}_{\mathrm{C}}[\mathrm{mg} / \mathrm{g}$ Biomass $]$ & $\mathrm{Y}_{\mathrm{C}}[\mathrm{mg} / \mathrm{L}]$ & Detected Carotenoids * \\
\hline \multicolumn{7}{|c|}{ First test group (at $25^{\circ} \mathrm{C}$ ) } \\
\hline WUT10 & $6.86 \pm 0.24$ & nd & $1.85 \pm 0.76$ & $0.23 \pm 0.02$ & $1.49 \pm 0.10$ & torularhodin \\
\hline WUT57 & $4.55 \pm 0.22$ & nd & a & $0.25 \pm 0.02$ & $1.10 \pm 0.10$ & torularhodin, $\beta$-carotene, $\gamma$-carotene \\
\hline WUT60 & $6.91 \pm 0.10$ & nd & $8.95 \pm 0.99$ & $0.11 \pm 0.01$ & $0.66 \pm 0.10$ & torularhodin \\
\hline WUT61 & $7.37 \pm 0.21$ & nd & a & $0.16 \pm 0.00$ & $1.18 \pm 0.00$ & torularhodin, $\beta$-carotene, $\gamma$-carotene, torulene \\
\hline WUT89 & $4.65 \pm 0.29$ & $9.09 \pm 0.15$ & $8.30 \pm 0.42$ & $0.09 \pm 0.01$ & $0.41 \pm 0.09$ & $\beta$-carotene, $\gamma$-carotene, torulene, torularhodin \\
\hline WUT92 & $7.55 \pm 0.25$ & nd & $22.30 \pm 1.56$ & $0.32 \pm 0.04$ & $2.62 \pm 0.03$ & $\begin{array}{l}\text { torularhodin, torulene, } \\
\beta \text {-carotene, } \gamma \text {-carotene }\end{array}$ \\
\hline WUT103 & $4.51 \pm 0.17$ & $9.25 \pm 0.67$ & $5.10 \pm 0.72$ & $0.05 \pm 0.01$ & $0.25 \pm 0.05$ & $\beta$-carotene, $\gamma$-carotene, torulene, torularhodin \\
\hline WUT117 & $4.42 \pm 0.06$ & $6.50 \pm 0.51$ & $8.00 \pm 0.57$ & $0.06 \pm 0.01$ & $0.31 \pm 0.04$ & $\beta$-carotene, $\gamma$-carotene, torularhodin, torulene \\
\hline \multicolumn{7}{|c|}{ Second test group (at $22^{\circ} \mathrm{C}$ ) } \\
\hline WUT128 & $7.10 \pm 0.26$ & nd & $25.70 \pm 5.52$ & $0.93 \pm 0.10$ & $6.61 \pm 0.92 \#$ & torularhodin, $\beta$-carotene, $\gamma$-carotene, torulene \\
\hline WUT145 & $6.70 \pm 0.90$ & nd & $7.40 \pm 0.42$ & $0.06 \pm 0.012$ & $0.62 \pm 0.02$ & torulene \\
\hline WUT147 & $9.70 \pm 1.27$ & nd & $13.85 \pm 3.61$ & $0.60 \pm 0.06$ & $6.00 \pm 0.52$ & torularhodin, $\beta$-carotene, $\gamma$-carotene, torulene \\
\hline WUT159 & $7.17 \pm 0.23$ & nd & $13.45 \pm 3.89$ & $0.75 \pm 0.06$ & $5.35 \pm 0.51$ & torularhodin, $\beta$-carotene, $\gamma$-carotene, torulene \\
\hline WUT165 & $9.07 \pm 0.75$ & nd & $4.20 \pm 0.28$ & $0.35 \pm 0.05$ & $3.06 \pm 0.09$ & torularhodin, $\beta$-carotene, torulene \\
\hline WUT167 & $8.67 \pm 0.32$ & nd & $8.95 \pm 1.34$ & $0.34 \pm 0.03$ & $3.09 \pm 0.21$ & torularhodin, $\beta$-carotene, torulene \\
\hline WUT182 & $9.23 \pm 0.21$ & nd & $19.70 \pm 0.28$ & $1.12 \pm 0.01$ & $10.33 \pm 0.24^{\#}$ & $\begin{array}{l}\text { torulene, torularhodin, } \\
\beta \text {-carotene, } \gamma \text {-carotene }\end{array}$ \\
\hline WUT194 & $5.97 \pm 0.15$ & nd & $7.70 \pm 0.99$ & $0.35 \pm 0.05$ & $3.06 \pm 0.09$ & torularhodin, $\beta$-carotene, $\gamma$-carotene \\
\hline
\end{tabular}




\subsubsection{Second Test Group—strains WUT128-WUT194}

Considerably better results were obtained with the remaining eight strains when the growth temperature was lowered to $22^{\circ} \mathrm{C}$. At the end of the cultivation, the DCW calculated was in a range of 5.97-9.70 g/L (Table 4). Quite like the first test group, carotenoid production was not directly linked with the production of yeast biomass. The weakest carotenoid biosynthesis, under tested conditions, was demonstrated by the strain $C$. macerans WUT145, for which the total carotenoid content reached value of $0.06 \pm 0.02 \mathrm{mg}$ carotenoids/g biomass. Almost a 3.4-fold higher result was obtained for the strain S. roseus WUT182, where the total carotenoid content was $1.12 \pm 0.01 \mathrm{mg}$ carotenoids/g biomass (Table 4 , Figure S4). The second best carotenoid producer was R. graminis WUT128 (0.93 $\pm 0.10 \mathrm{mg}$ carotenoids/g biomass). Among strains from this group, the carotenoid distribution is more even than in the first test group. Torularhodin constituted the main carotenoid component in five out of eight strains; the second pigment in terms of production was torulene. $\beta$-Carotene and $\gamma$-carotene were produced in a minority for almost all tested strains (except in R. graminis WUT194 and S. pararoseus WUT159).

\subsection{The Effect of Lower Temperatures on Carotenoid Synthesis in a Batch Cultures of Cystobasidium Species}

Little is known about the yeasts from the Cystobasidium genus; however, this group is extensively studied as of late. From the preliminary screening for carotenoid bio-production described above, newly isolated strains assigned to Cystobasidium sp. would also appear to be valuable producers of natural dyes. Therefore, it was decided to study them further in this respect.

The influence on carotenoids production has many factors, e.g., effect of the carbon to nitrogen $(\mathrm{C} / \mathrm{N})$ ratio, sources of nitrogen and carbon, mineral salts and incubation temperature. Because all newly isolated strains were well adapted to cooler temperatures, it was decided to first evaluate the influence of reduced temperature, between $20^{\circ} \mathrm{C}$ and $15^{\circ} \mathrm{C}$, on carotenoids biosynthesis. After a 4-day incubation biomass production, the presence of residual glucose concentration, lipids, and carotenoid production were determined (Table 5). For two strains, C. laryngis WUT89 and C. psychroaquaticum WUT117, the carotenoid output was linearly related with the temperature; the highest yields, $0.73 \pm 0.22 \mathrm{mg} / \mathrm{L}$ and $3.05 \pm 0.45 \mathrm{mg} / \mathrm{L}$ respectively, were achieved at $15^{\circ} \mathrm{C}$. At the same time, the biomass yield coefficient $\left(\mathrm{Y}_{\mathrm{XS}}\right)$ was also the highest $(0.60 \mathrm{~g}$ biomass/g substrate and $0.41 \mathrm{~g}$ biomass/g substrate for WUT89 and WUT117) and decreased with a rise in temperature (to $0.44 \mathrm{~g}$ biomass $/ \mathrm{g}$ substrate and $0.33 \mathrm{~g}$ biomass $/ \mathrm{g}$ substrate, respectively). When evaluating the carotenoid content, the same trend was identified for C. psychroaquaticum WUT117. No significant differences between the three tested temperature variants were observed for C. laryngis WUT89. It should be noted that the production of carotenoid pigments was not related with the biosynthesis of lipids. The highest amount was estimated at $20^{\circ} \mathrm{C}$ (between 2-4 times higher than at $15{ }^{\circ} \mathrm{C}$, and a staggering $10-16$ times higher at $25^{\circ} \mathrm{C}$ ) for both strains, and under these conditions, the highest glucose intake was also determined.

In contrast, the WUT92 strain behaved differently. The best carotenoid production occurred at $25^{\circ} \mathrm{C}, 2.62 \pm 0.03 \mathrm{mg} / \mathrm{L}, 0.32 \mathrm{mg} / \mathrm{g}$ biomass (Table 4), and was more than 2-times higher than at $15{ }^{\circ} \mathrm{C}, 0.92 \pm 0.06 \mathrm{mg} / \mathrm{L}, 0.14 \pm 0.00 \mathrm{mg} / \mathrm{g}$ biomass. When comparing these two variants, a near 2-fold difference was also determined in lipid biosynthesis, in favour of the higher temperature. Simultaneously, Cystobasidium sp. WUT92 metabolized all the glucose present in medium at $25^{\circ} \mathrm{C}$, and reached the highest biomass production but consuming only half the initial glucose amount at $15^{\circ} \mathrm{C}$. Intensified carotenoid production, unlike for the other two strains, was consequently linked with the decrease in the biomass yield coefficient. Similarly to WUT89 and WUT177, biosynthesis of lipids was the highest at $20^{\circ} \mathrm{C}$, and for WUT92 was associated with the lowest carotenoid output $(0.24 \pm 0.02 \mathrm{mg} / \mathrm{L})$.

The distribution of pigments produced varied among experiments. While at $25{ }^{\circ} \mathrm{C}$, the main pigments biosynthesized were $\beta$-carotene, $\gamma$-carotene, torulene and torularhodin, lowering the temperature significantly affected the distribution of the carotenoids, in favor for $\gamma$-carotene, and in one case (in culture of WUT92 at $20^{\circ} \mathrm{C}$ ) trace amounts of torularhodin. The chromatographic analyses revealed that also other, yet unknown carotenoid pigments were synthesized. Their identification 
requires, however, more complex analyses, such as e.g., HPLC-MS/MS [46]. These compounds may correspond to xanthophylls or to pigments from the apocarotenoid group. They could also be new, unfamiliar structures. Nevertheless, the strains used in the study are the species which are not well documented. The metabolic pathways leading to carotenoid synthesis in these strains are also still to be fully understood. Investigating the probable structure of pigments produced at a reduced temperature will be challenging, but it is certainly an attractive goal for further research, and could result in determining new species with interesting traits.

Table 5. The effect of temperature on carotenoid production in three Cystobasidium species. $X$-Biomass production, $\mathrm{L}$-lipidic extract, $\mathrm{C}_{\mathrm{C}}$ - total carotenoid content, $\mathrm{Y}_{\mathrm{C}}$-carotenoid output, nd-not detected. \# highest values.

\begin{tabular}{|c|c|c|c|c|c|c|}
\hline Strain & $X[g / L]$ & $\begin{array}{c}\text { Residual } \\
\text { Glucose }[\mathrm{g} / \mathrm{L}]\end{array}$ & L [mg] & $\begin{array}{l}\mathrm{C}_{\mathrm{C}}[\mathrm{mg} / \mathrm{g} \\
\text { Biomass] }\end{array}$ & $\mathrm{Y}_{\mathrm{C}}[\mathrm{mg} / \mathrm{L}]$ & $\begin{array}{c}\text { Detected } \\
\text { Carotenoids }\end{array}$ \\
\hline \multicolumn{7}{|c|}{$15^{\circ} \mathrm{C}$} \\
\hline WUT89 & $7.58 \pm 0.28$ & $7.45 \pm 0.24$ & $34.00 \pm 6.82$ & $0.10 \pm 0.03$ & $0.73 \pm 0.22$ \# & $\gamma$-carotene \\
\hline WUT92 & $6.48 \pm 0.38$ & $9.95 \pm 0.18$ & $12.35 \pm 1.71$ & $0.14 \pm 0.00$ & $0.92 \pm 0.06$ & $\gamma$-carotene \\
\hline WUT117 & $5.13 \pm 0.32$ & $7.42 \pm 0.13$ & $45.40 \pm 3.48$ & $0.54 \pm 0.08$ & $3.05 \pm 0.45^{\#}$ & $\gamma$-carotene \\
\hline \multicolumn{7}{|c|}{$20^{\circ} \mathrm{C}$} \\
\hline WUT89 & $7.15 \pm 0.82$ & $4.83 \pm 0.24$ & $\begin{array}{c}137.70 \pm \\
12.59\end{array}$ & $0.10 \pm 0.02$ & $0.58 \pm 0.14$ & $\gamma$-carotene \\
\hline WUT92 & $6.93 \pm 0.42$ & $6.85 \pm 0.27$ & $87.50 \pm 5.82$ & $0.15 \pm 0.04$ & $0.24 \pm 0.02$ & $\begin{array}{l}\gamma \text {-carotene, } \\
\text { torularhodin }\end{array}$ \\
\hline WUT117 & $6.43 \pm 0.30$ & $3.78 \pm 0.07$ & $85.35 \pm 4.19$ & $0.14 \pm 0.09$ & $1.05 \pm 0.30$ & $\gamma$-carotene \\
\hline
\end{tabular}

\subsection{The Impact of Glucose Concentration on Pigment Accumulation in R. mucilaginosa and} C. macerans Strains

Most yeast strains produce a mixture of pigments, with a varied composition. The biosynthesis of only one carotenoid in predominance seems to be atypical. Three strains isolated within this study, R. mucilaginosa WUT10 and WUT60, and C. macerans WUT145, exhibited this untypical trait in the preliminary tests (Table 4). The regulation of carotenoid production can be obtained by enhancing different factors associated with fermentation conditions [47]. Rhodotorula strains cultivated in medium containing a higher $\mathrm{C} / \mathrm{N}$ ratio generally showed positively affected carotenoid synthesis $[48,49]$; but this dependence is strain-specific. The above-mentioned strains were first cultivated in a medium containing $20 \mathrm{~g} / \mathrm{L}$ glucose, and under these conditions, their growth was limited (at the end of the culture biomass production reached between $6.7-6.9 \mathrm{~g} / \mathrm{L}$ ). In connection, the amount of synthesized carotenoids was also rather poor; it did not exceed $1.5 \mathrm{mg} / \mathrm{L}$. Therefore, in order to examine whether an increased glucose titer could influence both yeast growth and productivity, while maintaining a single-pigment bio-production; the glucose content was increased from $20 \mathrm{~g} / \mathrm{L}$ to 30 and $40 \mathrm{~g} / \mathrm{L}$ (Table 6).

This study revealed that initial glucose titer had a great impact on both the productivity and the ratio of produced pigments. Higher glucose titer led to increased formation of biomass; $10.75 \pm 0.35 \mathrm{~g} / \mathrm{L}$ $(30 \mathrm{~g} / \mathrm{L})$ and $16.60 \pm 0.70 \mathrm{~g} / \mathrm{L}(40 \mathrm{~g} / \mathrm{L})$ vs $6.86 \pm 0.24 \mathrm{~g} / \mathrm{L}(20 \mathrm{~g} / \mathrm{L}) ; 10.43 \pm 0.55 \mathrm{~g} / \mathrm{L}(30 \mathrm{~g} / \mathrm{L})$ and $13.37 \pm 0.55 \mathrm{~g} / \mathrm{L}(40 \mathrm{~g} / \mathrm{L})$ vs $6.91 \pm 0.01 \mathrm{~g} / \mathrm{L}(20 \mathrm{~g} / \mathrm{L})$, for R. mucilaginosa WUT10 and WUT60 strains respectively; while negatively affecting pigments production. For both strains we observed a fall of between $26 \%$ and $59 \%$ in the total carotenoid content, accompanied by a lower yield of torularhodin (main carotenoid and the only detected upon cultivation on lower glucose titer) and the production of an additional pigment, $\gamma$-carotene or $\beta$-carotene. This may indicate some changes in the metabolic pathways, since $\gamma$-carotene is a direct precursor of $\beta$-carotene, and indirect of torularhodin [50]. In the case of $C$. macerans WUT145, similar to the other two strains, a higher glucose content influenced the intensified biomass production (up to 2-fold increase) in connection with the definite enhancement of carotenoid biosynthesis; the maximum carotenoid content was obtained at $40 \mathrm{~g} / \mathrm{L}$ 
glucose, $1.72 \pm 0.08 \mathrm{mg} / \mathrm{L}(0.13 \pm 0.01 \mathrm{mg} / \mathrm{g}$ biomass $)$ which was almost a 3-fold increase when compared to the initial cultures. Although, in comparison to C. macerans strain tested by Marova et al., 2017 [48], which produced $1.98 \mathrm{mg}$ carotenoids/g DCW on animal fat wastes, C. macerans WUT145 produced significantly less carotenoids; yet this strain has the potential to enhance its production, even on media containing alternative carbon sources deriving from wastes from various industries, thanks to its ability to secrete diverse extracellular enzymes. The productivity of individual pigments employing different media was also changed. The predominance of torulene was replaced by a mixture of torulene, torularhodin and $\gamma$-carotene. C. macerans WUT145 biosynthesize also small amounts of unidentified carotenoids under tested conditions.

Table 6. Influence of increased glucose concentration on carotenoid production and pigment distribution by R. mucilaginosa and C. macerans strains. " highest values.

\begin{tabular}{|c|c|c|c|c|c|c|c|}
\hline \multirow{2}{*}{ Strain } & \multirow{2}{*}{$X[g / L]$} & \multirow{2}{*}{$\begin{array}{l}\mathrm{C}_{\mathrm{C}}[\mathrm{mg} / \mathrm{g} \\
\text { Biomass }]\end{array}$} & \multirow{2}{*}{$\mathrm{Y}_{\mathrm{C}}[\mathrm{mg} / \mathrm{L}]$} & \multicolumn{4}{|c|}{ Carotenoid Distribution [mg/L] } \\
\hline & & & & $\beta$-Carotene & $\gamma$-Carotene & Torulene & Torularhodin \\
\hline \multicolumn{8}{|c|}{$30 \mathrm{~g} / \mathrm{L}$ glucose } \\
\hline 10 & $10.75 \pm 0.35$ \# & $0.04 \pm 0.00$ & $0.38 \pm 0.05$ & $0.06 \pm 0.01$ & 0 & 0 & $0.32 \pm 0.04$ \\
\hline 60 & $10.43 \pm 0.55$ & $0.02 \pm 0.00$ & $0.17 \pm 0.03$ & 0 & $0.04 \pm 0.01$ & 0 & $0.15 \pm 0.02$ \\
\hline 145 & $10.43 \pm 1.27$ & $0.08 \pm 0.03$ & $0.95 \pm 0.06$ & 0 & $0.33 \pm 0.02$ & $0.24 \pm 0.04$ & $0.13 \pm 0.01$ \\
\hline \multicolumn{8}{|c|}{$40 \mathrm{~g} / \mathrm{L}$ glucose } \\
\hline 10 & $16.60 \pm 0.70$ & $0.04 \pm 0.01$ & $0.64 \pm 0.11$ & 0 & $0.07 \pm 0.01$ & 0 & $0.64 \pm 0.04$ \\
\hline 60 & $13.37 \pm 0.55$ & $0.04 \pm 0.01$ & $0.39 \pm 0.06$ & 0 & $0.05 \pm 0.01$ & 0 & $0.34 \pm 0.05$ \\
\hline 145 & $13.37 \pm 0.55$ & $0.13 \pm 0.01$ & $1.72 \pm 0.08^{\#}$ & 0 & $0.51 \pm 0.02$ & $0.56 \pm 0.04$ & $0.23 \pm 0.03$ \\
\hline
\end{tabular}

\section{Conclusions}

The need for natural carotenoids has triggered research to examine commercially viable processes for their cost-effective production. The chemical synthesis of carotenoids is both expensive and challenging. Their extraction from raw materials is often limited by the source availability and the financial aspects. Therefore, an increasing interest in microbial sources for carotenoids has been observed. To date, in the literature, species of yeast strains, such as Phaffia rhodozyma, Rhodotorula spp., are described in detail. However, little is known about other non-conventional yeasts.

In this study, sixteen red-pink pigmented yeast strains were isolated and were classified into five genera: Rhodotorula, Cystobasidium, Sporobolomyces, Sporidiobolus and Cystofilobasidium. All of the newly selected yeasts were able to synthesize carotenoid pigments under tested conditions. In the preliminary tests, the highest carotenoid accumulation showed strains Sporobolomyces roseus WUT182, which was able to produce $1.12 \pm 0.01 \mathrm{mg}$ pigments/g biomass and Rhodotorula graminis WUT128, $0.93 \pm 0.10 \mathrm{mg}$ pigments/g biomass, but these strains differ in the distribution of carotenoids. It is worth emphasizing that, amongst the newly isolated strains, we found ones from the Cystobasidium cluster that are still poorly recognized in this respect, and therefore, the results obtained during this work are extremely valuable data. Interestingly, all the strains, although not collected from polar regions, are psychrophilic (optimal growth temperatures between $4^{\circ} \mathrm{C}$ and $22^{\circ} \mathrm{C}$ ). For two strains C. laryngis WUT89 and C. psychroaquaticum WUT117 reducing the growth temperature resulted in a 10 -fold increase in carotenoid synthesis. Further research on the optimization of culture conditions may probably bring subsequent increase in productivity.

As expected, most of isolated yeasts biosynthesized extracellular lipases. However, more interestingly, within the tested group, four cellulolytic strains (S. roseus WUT61, C. macerans WUT145, S. pararoseus WUT159 and S. roseus WUT182) and one proteolytic (C. macerans WUT145) were also revealed. Strains exhibiting the ability to secrete enzymes, and therefore utilize various organic wastes as substrates for their growth, can be considered alone or in mixed-culture fermentations for a development of carotenoids production on agro-industrial waste, e.g., lignocellulose or whey. 
However, additional experiments will be needed to design such processes to determine both the optimum growth temperature, the optimum cellulase/protease secretion temperature and the optimum carotenoid production temperature. Also the relation between this parameters will be key when developing technologies based on organic wastes. Furthermore, it would be interesting also to study in more detail enzymatic activity of selected yeast strains, as this group of enzymes has numerous applications; e.g., in the processing of fats and oils, as additives for detergents and degreasing agents, in food processing, in chemical and pharmaceutical synthesis, in the production of paper, the food and feed industry, agriculture and in the cosmetics industry [51,52].

Supplementary Materials: The following are available online at http://www.mdpi.com/2076-2607/7/12/653/s1, Figure S1. Lipase activity plate tests after (a) $24 \mathrm{~h}$ and (b) $48 \mathrm{~h}$ incubation. The selected yeast cultures were grown at $22^{\circ} \mathrm{C}$ on plates containing Spirit Blue agar (Becton Dickinson, New Jersey, USA) with $20 \%(\mathrm{v} / \mathrm{v})$ emulsion olive oil/Tween 80 . The expression of lipolytic enzymes was confirmed by a zone of clearance around the colony. Activity was determined based on results after $24 \mathrm{~h}$ incubation (Table 2 in main manuscript). Figure S2. Protease activity plate tests. The protease activity was tested on nutrient agar supplemented with $2 \%$ starch. The selected yeast cultures were grown at $22{ }^{\circ} \mathrm{C}$ for 3 days. The expression of proteases was confirmed by a zone of clearance around the colony. Figure S3. Cellulase activity plate tests. Cellulolytic activity was tested on yeast nitrogen base without aminoacids and with ammonium sulfate with $\%$ CMC. The selected yeast cultures were grown at $22{ }^{\circ} \mathrm{C}$ for 3 days. The positive expression of cellulase activity was indicated by a zone of clearance around the colony, which was visualized more clearly after pouring Lugol's iodine onto the plate and incubating plates for $5 \mathrm{~min}$. Figure S4. Typical HPLC-chromatogram of carotenoid extract obtained from batch culture of WUT165 recorded at $450 \mathrm{~nm}$ using diode array detector. Each carotenoid pigment was identified at the wavelength of maximum peak absorbance: torularhodin $(\lambda \max 507 \mathrm{~nm}$; retention time $11.5 \mathrm{~min}$, torulene $(\lambda \max 484 \mathrm{~nm}$; retention time $13.4 \mathrm{~min})$, $\beta$-carotene $(\lambda \max 450 \mathrm{~nm}$; retention time $\sim 15.0 \mathrm{~min}$ ). Table $S 1$. Cell size measurements. Cell sizes were calculated from at least 100 cells grown on SAB agar plates for 3 days at $22{ }^{\circ} \mathrm{C}$. Microscopic observations were conducted through a $100 \times$ objective lens under brightfield (Levenhuk D870T with ToupView software).

Author Contributions: Conceptualization, K.C., J.M.; Methodology, K.C., J.M., J.T., M.M., M.C.; Formal Analysis, K.C., J.M., J.T.; Investigation, K.C., J.M., J.T., M.M.; Data Curation, K.C., J.M.; Writing-Original Draft Preparation, K.C.; Writing-Review \& Editing, K.C., J.M.; Visualization, K.C., J.M.; Funding Acquisition, J.M., K.C., M.C.

Funding: This research was funded by the National Science Centre, Poland (2016/21/D/NZ9/01605), by the European Cooperation in Science and Technology (under eCOST Action CA15136-EUROCAROTEN), by the Warsaw University of Technology, Faculty of Chemistry and by the Ministry of Education, Science, Research and Sport of the Slovak Republic (grant VEGA 1/0343/19).

Acknowledgments: Authors would like to acknowledge Eliza Korzeniowska for her technical assistance, Irena Puzio, Anna Sobiepanek and students from the science club "HERBION" at Warsaw University of Technology for probes of environmental samples, the source of some yeast strains.

Conflicts of Interest: The authors declare no competing interests.

\section{References}

1. Tsuji, M.; Tsujimoto, M.; Imura, S. Cystobasidium tubakii and Cystobasidium ongulense, new basidiomycetous yeast species isolated from East Ongul Island, East Antarctica. Mycoscience 2017, 58, 103-110. [CrossRef]

2. Choudhary, D.K.; Bhavdish, N.J. Basidiomycetous Yeasts: Current Status. In Yeast Biotechnology: Diversity and Applications; Satyanarayana, T., Kunze, G., Eds.; Springer Nature: Dordrecht, The Netherlands, 2009; pp. 19-43.

3. Tao, B.Y. Industrial Applications for Plant Oils and Lipids. Bioprocess. Value-Added Prod. Renew. Resour. 2007, 611-627. [CrossRef]

4. Aksu, Z.; Eren, T.A. Carotenoids production by the yeast Rhodotorula mucilaginosa: Use of agricultural wastes as a carbon source. Process Biochem. 2005, 40, 2985-2991. [CrossRef]

5. Tinoi, J.; Rakariyatham, N.; Deming, R.L. Simplex optimization of carotenoid production by Rhodotorula glutinis using hydrolyzed mung bean waste flour as substrate. Process Biochem. 2005, 40, 2551-2557. [CrossRef]

6. Kot, A.M.; Błazejak, S.; Gientka, I.; Kieliszek, M.; Bryś, J. Torulene and torularhodin: 'New' fungal carotenoids for industry? Microb. Cell Fact. 2018, 17, 49. [CrossRef] [PubMed]

7. Davoli, P.; Weber, R. Carotenoid pigments from the red mirror yeast, Sporobolomyces roseus. Mycologist 2002, 16, 102-108. [CrossRef] 
8. Hu, Z.C.; Zheng, Y.G.; Wang, Z.; Shen, Y.C. Effect of sugar-feeding strategies on astaxanthin production by Xanthophyllomyces dendrorhous. World J. Microbiol. Biotechnol. 2005, 21, 771-775. [CrossRef]

9. Ramírez, J.; Obledo, N.; Arellano, M.; Herrera, E. Astaxanthin production by Phaffia rhodozyma in a fedbatch culture using a low cost medium feeding. e-Gnosis 2006, 4, 1-9.

10. Ni,H.; Chen, Q.; He, G.; Wu, G.; Yang, Y. Optimization of acidic extraction of astaxanthin from Phaffia rhodozyma. J. Zhejiang Univ. Sci. B 2008, 9, 51-59. [CrossRef]

11. Stolarzewicz, I.; Kapturowska, A.; Białecka-Florjańczyk, E. Mikrobiologiczne źródła barwników w technologii żywności. Postep. Mikrobiol. 2012, 51, 167-176.

12. Barredo, J.L.; Garc, C.; Kosalkova, K.; Barreiro, C. Biosynthesis of astaxanthin as a main carotenoid in the Heterobasidiomycetous yeast Xanthophyllomyces dendrorhous. J. fungi 2017, 3, 44. [CrossRef] [PubMed]

13. Mata-Gómez, L.C.; Montañez, J.C.; Méndez-Zavala, A.; Aguilar, C.N. Biotechnological production of carotenoids by yeasts: An overview. Microb. Cell Fact. 2014, 13, 1-11. [CrossRef] [PubMed]

14. Stahl, W.; Sies, H. Carotenoids and protection against solar UV radiation. Skin Pharmacol. Appl. Skin Physiol. 2002, 15, 291-296. [CrossRef] [PubMed]

15. Fraser, P.D.; Bramley, P.M. The biosynthesis and nutritional uses of carotenoids. Prog. Lipid Res. 2004, 43, 228-265. [CrossRef] [PubMed]

16. Ye, V.M.; Bhatia, S.K. Pathway engineering strategies for production of beneficial carotenoids in microbial hosts. Biotechnol. Lett. 2012, 34, 1405-1414. [CrossRef] [PubMed]

17. Peralta, R.M.; da Silva, B.P.; Côrrea RC, G.; Kato, C.G.; Seixas FA, V.; Bracht, A. Enzymes from Basidiomycetes-Peculiar and Efficient Tools for Biotechnology. In Biotechnology of Microbial Enzymes; Brahmachari, G., Ed.; Academic Press: Cambridge, MA, USA, 2017; pp. 119-149. [CrossRef]

18. Mendonça Maciel, M.; Castro e Silva, A.; Camarão Telles Ribeiro, H. Industrial and biotechnological applications of ligninolytic enzymes of the basidiomycota: A review. Electron. J. Biotechnol. 2010, 13, 1-13. [CrossRef]

19. Tanimura, A.; Sugita, T.; Endoh, R.; Ohkuma, M.; Kishino, S.; Ogawa, J.; Shima, J.; Takashima, M. Lipid production via simultaneous conversion of glucose and xylose by a novel yeast, Cystobasidium iriomotense. PLoS ONE 2018, 13, e0202164. [CrossRef]

20. Vyas, S.; Chhabra, M. Isolation, identification and characterization of Cystobasidium oligophagum JRC1: A cellulase and lipase producing oleaginous yeast. Bioresour. Technol. 2017, 223, 250-258. [CrossRef]

21. Rönnander, J.; Ljunggren, J.; Hedenström, E.; Wright, S.A.I. Biotransformation of vanillin into vanillyl alcohol by a novel strain of Cystobasidium laryngis isolated from decaying wood. AMB Express 2018, 8, 4-11. [CrossRef]

22. Chreptowicz, K.; Sternicka, M.K.; Kowalska, P.D.; Mierzejewska, J. Screening of yeasts for the production of 2-phenylethanol (r ose aroma) in organic waste-based media. Lett. Appl. Microbiol. 2018, 66, 153-160. [CrossRef]

23. Chreptowicz, K.; Wielechowska, M.; Główczyk-Zubek, J.; Rybak, E.; Mierzejewska, J. Production of natural 2-phenylethanol: From biotransformation to purified product. Food Bioprod. Process. 2016, 100, $275-281$. [CrossRef]

24. Adame-Soto, P.J.; Aréchiga-Carvajal, E.T.; López, M.G.; González-Herrera, S.M.; Moreno-Jiménez, M.R.; Urtiz-Estrada, N.; Rutiaga-Quiñones, O.M. Potential production of 2-phenylethanol and 2-phenylethylacetate by non-Saccharomyces yeasts from Agave durangensis. Ann. Microbiol. 2019, 69, 989-1000. [CrossRef]

25. Ghose, T.K. Measurement of cellulase activities. Pure Appl. Chem. 1987, 59, 257-268. [CrossRef]

26. Tkáčová, J.; Klempová, T.; Čertík, M. Kinetic study of growth, lipid and carotenoid formation in $\beta$-carotene producing Rhodotorula glutinis. Chem. Pap. 2018, 72, 1193-1203. [CrossRef]

27. Kumar, S.; Stecher, G.; Li, M.; Knyaz, C.; Tamura, K. MEGA X: Molecular Evolutionary Genetics Analysis across computing platforms. Mol Biol Evol. 2018, 35, 547-1549. [CrossRef] [PubMed]

28. Coronado-Ruiz, C.; Avendaño, R.; Escudero-Leyva, E.; Conejo-Barboza, G.; Chaverri, P.; Chavarría, M. Two new cellulolytic fungal species isolated from a 19th-century art collection. Sci. Rep. 2018, 8, 1-9. [CrossRef]

29. Zieniuk, B.; Fabiszewska, A. Yarrowia lipolytica: a beneficious yeast in biotechnology as a rare opportunistic fungal pathogen: a minireview. World J. Microbiol. Biotechnol. 2019, 35, 10. [CrossRef]

30. Schlander, M.; Distler, U.; Tenzer, S.; Thines, E.; Claus, H. Purification and properties of yeast proteases secreted by Wickerhamomyces anomalus 227 and Metschnikovia pulcherrima 446 during growth in a white grape juice. Fermentation 2016, 3, 2. [CrossRef] 
31. Larios, A.; García, H.S.; Oliart, R.M.; Valerio-Alfaro, G. Synthesis of flavor and fragrance esters using Candida antarctica lipase. Appl. Microbiol. Biotechnol. 2004, 65, 373-376. [CrossRef]

32. Taskin, M.; Ucar, M.H.; Unver, Y.; Kara, A.A.; Ozdemir, M.; Ortucu, S. Lipase production with free and immobilized cells of cold-adapted yeast Rhodotorula glutinis HL25. Biocatal. Agric. Biotechnol. 2016, 8, 97-103. [CrossRef]

33. Papaparaskevas, D.; Christakopoulos, P.; Kekos, D.; Macris, B.J. Optimizing production of extracellular lipase from Rhodotorula glutinis. Biotechnol. Lett. 1992, 14, 397-402. [CrossRef]

34. Weber, R.W.S.; Anke, H.; Davoli, P. Simple method for the extraction and reversed-phase high-performance liquid chromatographic analysis of carotenoid pigments from red yeasts (Basidiomycota, Fungi). J. Chromatogr. A 2007, 1145, 118-122. [CrossRef] [PubMed]

35. Smaniotto, A.; Skovronski, A.; Rigo, E.; Tsai, S.M.; Durrer, A.; Foltran, L.L.; di Luccio, M.; Oliveira, J.V.; de Oliveira, D.; Treichel, H. 'Synthetic lipase' production from a newly isolated Sporidiobolus pararoseus strain by submerged fermentation. Brazilian J. Microbiol. 2012, 43, 1490-1498. [CrossRef]

36. Daskaya-Dikmen, C.; Karbancioglu-Guler, F.; Ozcelik, B. Cold active pectinase, amylase and protease production by yeast isolates obtained from environmental samples. Extremophiles 2018, 22, 599-606. [CrossRef] [PubMed]

37. Sabotič, J.; Trcek, T.; Popovic, T.; Brzin, J. Basidiomycetes harbour a hidden treasure of proteolytic diversity. J. Biotechnol. 2007, 128, 297-307. [CrossRef]

38. Alias, N.; Ahmad Mazian, M.; Salleh, A.B.; Basri, M.; Rahman, R.N.Z.R.A. Molecular cloning and optimization for high level expression of cold-adapted serine protease from antarctic yeast glaciozyma antarctica PI12. Enzyme Res. 2014, 2014, 197938. [CrossRef]

39. Pi, H.W.; Anandharaj, M.; Kao, Y.Y.; Lin, Y.J.; Chang, J.J.; Li, W.H. Engineering the oleaginous red yeast Rhodotorula glutinis for simultaneous $\beta$-carotene and cellulase production. Sci. Rep. 2018, 8, 2-11. [CrossRef]

40. Mierzejewska, J.; Dabkowska, K.; Chreptowicz, K.; Sokołowska, A. Hydrolyzed corn stover as a promising feedstock for 2-phenylethanol production by nonconventional yeast. J. Chem. Technol. Biotechnol. 2019, 94, 777-784. [CrossRef]

41. Baldrian, P.; Valášková, V. Degradation of cellulose by basidiomycetous fungi. FEMS Microbiol. Rev. 2008, 32, 501-521. [CrossRef]

42. Rong, Y.; Zhang, L.; Chi, Z.; Wang, X. A carboxymethyl cellulase from a marine yeast (Aureobasidium pullulans 98): Its purification, characterization, gene cloning and carboxymethyl cellulose digestion. J. Ocean Univ. China 2015, 14, 913-921. [CrossRef]

43. Neto, A.A.K.; Borin, G.P.; Goldman, G.H.; de Lima Damásio, A.R.; de Castro Oliveira, J.V. Insights into the plant polysaccharide degradation potential of the xylanolytic yeast Pseudozyma brasiliensis. FEMS Yeast Res. 2016, 16, 117. [CrossRef] [PubMed]

44. Johnsen, H.R.; Krause, K. Cellulase activity screening using pure carboxymethylcellulose: Application to soluble cellulolytic samples and to plant tissue prints. Int. J. Mol. Sci. 2014, 15, 830-838. [CrossRef] [PubMed]

45. Irazusta, V.; Nieto-Peńalver, C.G.; Cabral, M.E.; Amoroso, M.J.; Figueroa, L.I.C. Relationship among carotenoid production, copper bioremediation and oxidative stress in Rhodotorula mucilaginosa RCL-11. Process Biochem. 2013, 48, 803-809. [CrossRef]

46. Rivera Velez, S.M. Guide for carotenoid identification in biological samples. J. Nat. Prod. 2016, 79, 1473-1484. [CrossRef]

47. Hernandez-Almanza, A.; Montanez, J.C.; Aguilar-Gonzalez, M.A.; Martínez-Ávila, C.; Rodríguez-Herrera, R.; Aguilar, C.N. Rhodotorula glutinis as source of pigments and metabolites for food industry. Food Biosci. 2014, 5, 64-72. [CrossRef]

48. Marova, I.; Szotkowski, M.; Vanek, M.; Rapta, M.; Byrtusova, D.; Mikheichyk, N.; Haronikova, A.; Shapaval, M.C. Utilization of animal fat waste as carbon source by carotenogenic yeasts - a screening study. EuroBiotech J. 2017, 1, 310-318. [CrossRef]

49. Braunwald, T.; Schwemmlein, L.; Graeff-Hönninger, S.; French, W.T.; Hernandez, R.; Holmes, W.E.; Claupein, W. Effect of different C/N-ratios on carotenoid and lipid production by Rhodotorula glutinis. Appl. Microbiol. Biotechnol. 2013, 6581-6588. [CrossRef]

50. Sperstad, S.; Lutnæs, B.F.; Stormo, S.K.; Liaaen-Jensen, S.; Bjarne, L. Torularhodin and torulene are the major contributors to the carotenoid pool of marine Rhodosporidium babjevae (Golubev). J. Ind. Microbiol. Biotechnol. 2006, 33, 269. [CrossRef] 
51. Houde, A.; Kademi, A.; Leblanc, D. Lipases and their industrial applications: an overview. Appl. Biochem. Biotechnol. 2004, 118, 155-170. [CrossRef]

52. Kuhad, R.C.; Gupta, R.; Singh, A. Microbial Cellulases and Their Industrial Applications. Enzyme Res. 2011, 2011, 280696. [CrossRef] 